Vaneasa Online Journal

$5.1 \mid 2017$

Varia 5.1

\title{
Editorial Anthrovision Issue 5.1
}

\section{Beate Engelbrecht}

\section{(2) OpenEdition \\ Journals}

Electronic version

URL: http://journals.openedition.org/anthrovision/2604

DOI: 10.4000/anthrovision.2604

ISSN: 2198-6754

\section{Publisher}

VANEASA - Visual Anthropology Network of European Association of Social Anthropologists

\section{Electronic reference}

Beate Engelbrecht, «Editorial Anthrovision Issue 5.1 », Anthrovision [Online], 5.1 | 2017, Online since 01 December 2017, connection on 24 September 2020. URL : http://journals.openedition.org/ anthrovision/2604; DOI : https://doi.org/10.4000/anthrovision.2604

This text was automatically generated on 24 September 2020

(c) Anthrovision 


\title{
Editorial Anthrovision Issue 5.1
}

\author{
Beate Engelbrecht
}

2 after three issues with special thematic foci, AnthroVision publishes now another "varia" issue. Nonetheless, this issue concentrates on questions of methodology concerning ethnographic film, film ethnography, and visual ethnography.

In their article 'Software as Co-Teacher: How Korsakow Disrupted an Ethnographic Film Program' Torsten Näser and Franziska Weidle present their experiences of using Korsakow in teaching visual anthropology. They reflect critically on the co-constitution of technology and practice within the student research project's particular "materiality of learning". Cristóbal Escobar's article, 'The Colliding Worlds of Anthropology and Film-Ethnography' discusses three consecutive periods when the anthropology and film ethnography collide: Bronislaw Malinowski and Robert Flaherty's Nanook of the North; the influence of Marcel Mauss on Jean Rouch's cinéma-vérité; and the anthropology of Eduardo Viveiros de Castro's engagement with Harvard's Sensory Ethnographic Lab's film Leviathan. Lorenzo Ferrarini's article 'Embodied Representation: Audiovisual Media and Sensory Ethnography' takes up the perspective of sensory ethnography and reviews the work of Jean Rouch and Steven Feld, underlining how they developed specific recording technologies that allowed them to give to their media work an embodied character. Ferrarini then considers the relationship between sensory media and interaction with reference to the work of Merleau-Ponty, stressing how from a phenomenological perspective an embodied camera is always an interactive camera. Andrew Stevenson and Rebecca Lawthom's article 'How We Know Each Other: Exploring the Bonds of Friendship Using Friendship Ethnography and Visual Ethnography' shows how they use film and interviews to explore the practices that cement friendship bonds. Situating the research among friends and treating participants according to the ethics of friendship draws them closer to an understanding of the nature of their relationships. 


\section{AUTHOR}

BEATE ENGELBRECHT

Director of Anthrovision 